$\underline{\text { www.scielo.br/eq }}$

\title{
Dielectric spectroscopy and thermally stimulated discharge current in PEEK film
}

\author{
W. K. Sakamoto \\ Departamento de Física e Química - FEG/UNESP - CEP 15385-000 \\ Ilha Solteira $-\mathrm{SP}-$ Brasil
}

\begin{abstract}
The complex permittivity of films of polyether ether ketone (PEEK) has been investigated over a wide range of frequency. There is no relaxation peak in the range of $1 \mathrm{~Hz}$ to $10^{5} \mathrm{~Hz}$ but in the lowfrequency side $\left(10^{-4} \mathrm{~Hz}\right)$ there is an evidence of a peak that also can be observed by thermally stimulated discharge current measurements. That peak is related with the glass transition temperature $\left(\mathrm{T}_{\mathrm{g}}\right)$ of the polymer. The activation energy of the relaxation was found to be $0.44 \mathrm{eV}$, similar to that of several synthetic polymers. Space charges are important in the conduction mechanism as shown by discharging transient.
\end{abstract}

Keywords: dielectric loss; thermally stimulated discharge current; polymer; activation energy; glass transition temperature.

\section{Introduction}

Polyether ether ketone (PEEK) is an aromatic polyether. It has been developed by I. C. I. Petrochemicals and Plastic Division as a hightemperature engineering thermoplastic [1]. Because of the symmetry of the benzene rings along the polymer backbone, PEEK offers mechanical strength and from the characteristic of almost linear chemical structure, the polymer has a crystalline phase.

PEEK is also resistant to an extraordinary range of chemicals and has very low emission of smoke and toxic fumes when exposed to a flame [2]. Due to characteristics such as: melting point over $300^{\circ} \mathrm{C}$; low dielectric loss; resistance to attack by several chemical solvents and insulating properties, PEEK has considerable applications as an engineering material [3]. Nowadays there is high interest for the use of PEEK as a matrix for ferroelectric-ceramic/polymer composites as nondestructive testing sensors.
Although PEEK has already been used as insulating material and its electrical and dielectric properties have been reported $[4,5]$, this paper reports results of dielectric spectroscopy in the wide frequency range of $10^{-5} \mathrm{~Hz}$ to $10^{5} \mathrm{~Hz}$ and the nature of the thermally stimulated discharge current (TSDC) in the temperature range from $10{ }^{\circ} \mathrm{C}$ to above glass transition temperature $\left(\mathrm{T}_{\mathrm{g}}\right)$ is analyzed.

\section{Experimental}

Commercial samples of $25 \mathrm{~mm}$ PEEK film were used in this work. Polyether ether ketone is an engineering thermoplastic with high performance. It belongs to a class of polyaryletherketone (PAEK) which are characterized by the presence of benzene rings linked with oxygen and ketone groups. The chemical structure of PEEK is shown in figure 1. The pair of ether linkages - $\mathrm{O}$ - in the chain backbone gives to the PEEK's chain flexibility and ability to crystallize [2].

E-mail: sakamoto@fqm.feis.unesp.br 


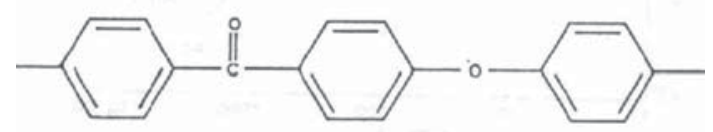

Figure 1. Chemical formula of polyether ether ketone (PEEK) from I.C.I.

The samples were cleaned with alcohol and aluminium electrodes of circular area of 1.0 $\mathrm{cm}$ diameter were deposited onto both sides of the samples. The dielectric data were taken using an impedance analyzer model HP 4192A in the frequency range of $20 \mathrm{~Hz}$ to $10^{5} \mathrm{~Hz}$. For the medium frequency range of $5 \times 10^{-2} \mathrm{~Hz}$ to $10 \mathrm{~Hz}$, a Lock-In amplifier model EG\&G 7265 was used. In the low frequency range of $10^{-5} \mathrm{~Hz}$ to $3 \times 10^{-2}$ $\mathrm{Hz}$ the time domain technique of the measurement of discharge current with subsequent Hamon [6] approximation method were used.

For discharge current measurement, the PEEK film was placed in an evacuated chamber and a Keithley 247 high voltage supply was used to charge the sample at a field of $10^{6} \mathrm{~V} / \mathrm{m}$ for a period of 27 hours. The discharge current was measured for 3.0 hours. For the thermally stimulated discharge current (TSDC) measurement a TSC measuring system form Toyo Seiki, with a temperature controlled chamber was used and the currents were monitored with a Keithley 610 C electrometer suitably fed to a microcomputer.

\section{Results and discussion}

Figure 2 shows the behavior of the complex permittivity for PEEK at room temperature. The low-frequency $\left(10^{-5} \mathrm{~Hz}\right.$ to $10^{-2}$ $\mathrm{Hz}$ ) data of the dielectric loss $\left(\mathrm{e}^{2}\right)$ were calculated from transient discharge current measurement, using the following equation,

$\varepsilon^{2}=\frac{I_{d}}{2 \pi f C_{0} V}$

where $I_{d}$ is the discharge current measured for $3 \mathrm{~h}$ after charging the sample for $27 \mathrm{~h}$ with a $10^{5} \mathrm{~V} / \mathrm{m}$ electric field, $f=0.1 / t$ is the Hamon [6] frequency,
$\mathrm{C}_{0}$ is the capacitance of measuring electrodes without the sample and $\mathrm{V}$ is the charging voltage. Considering that the measurement of the discharge current start $5 \mathrm{sec}$. After the removal the applied voltage and short-circuit the electrodes, the frequency range obtained is $2 \times 10^{-2} \mathrm{~Hz}$ to $9 \times 10^{-6}$ $\mathrm{Hz}$ due to Hamon approximation ( $\mathrm{f}=0.1 / \mathrm{t}$ ).

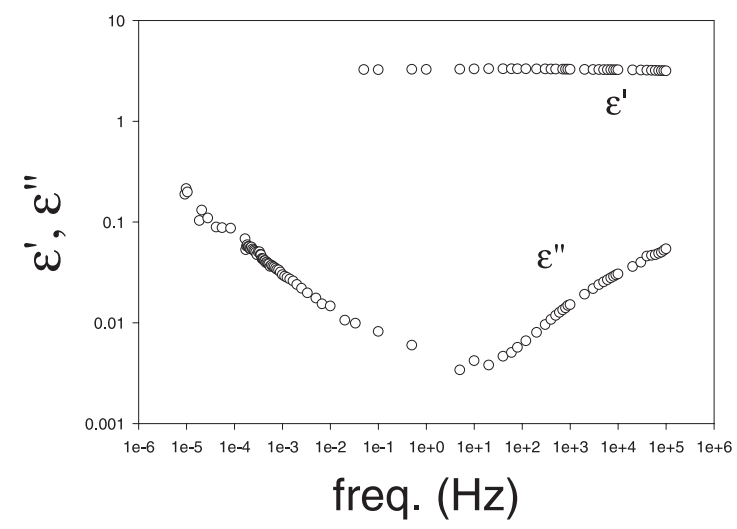

Figure 2. Dielectric behavior of PEEK film at room temperature.

The low-frequency permittivity $\left(\varepsilon^{\prime}\right)$ values can be calculated using the well-known KramersKronig relation [7]. In the frequency range of $10^{-2}$ $\mathrm{Hz}$ to $10 \mathrm{~Hz}$ both $\varepsilon^{\prime}$ and $\varepsilon^{\prime \prime}$ were obtained experimentally using a lock-in amplifier. A sinusoidal voltage was applied to the sample and both the in-phase and $90{ }^{\circ} \mathrm{C}$ out-of-phase currents were measured. The permittivity and dielectric loss were calculated by [8],

$$
\begin{aligned}
\mathrm{e}^{\prime} & =\frac{\mathrm{we}^{t I_{y}}}{{ }_{0} A V} \\
\varepsilon^{\prime \prime} & =\frac{t I_{x}}{\omega \varepsilon_{0} A V}
\end{aligned}
$$

where $t$ is the sample thickness, $\omega$ is the angular frequency, $\mathrm{A}$ is the electrode area, $\mathrm{V}$ the applied voltage, $\varepsilon_{0}=8,85 \times 10^{-12} \mathrm{~F} / \mathrm{m}$ is the vacuum permittivity, $\mathrm{I}_{\mathrm{x}}$ and $\mathrm{I}_{\mathrm{y}}$ are the quadrature and in-phase currents, respectively. 
From $20 \mathrm{~Hz}$ to $10^{6} \mathrm{~Hz}$ the conventional bridge can be used with very good accuracy and the complex permittivity can be obtained by measuring the capacitance of the sample as a function of the frequency.

It can be seen from figure 2 that no loss process is centered in the frequency range of 1.0 to $10^{5} \mathrm{~Hz}$. The increase of $\mathrm{e}^{2}$ at high frequency indicates that the loss process might be occurs in the frequency range $(\mathrm{MHz})$ outside the frequency range of the present work. The absence of loss peak in that frequency range is compatible with the flat behavior of the permittivity.

On the low-frequency side there is an evidence of a peak around $10^{-4} \mathrm{~Hz}$ in the dielectric loss (e"). This peak might be related with the glass transition of the polymer. Actually, the relaxation at low-frequency due to glass transition (a relaxation) can be seen by thermally stimulated discharge current (TSDC) measurements. Figure 3 shows a typical TSDC spectrum. The sample was poled with $10^{7} \mathrm{~V} / \mathrm{m}$ electric field for $30 \mathrm{~min}$ at $150{ }^{\circ} \mathrm{C}$. The sample was cooled at $0{ }^{\circ} \mathrm{C}$ under applied field and after 30 min with the electrodes short-circuited, the discharge current was measured with a heating rate of $1 \mathrm{degree} / \mathrm{min}$. The a relaxation related with the glass transition was observed at $90{ }^{\circ} \mathrm{C}$.

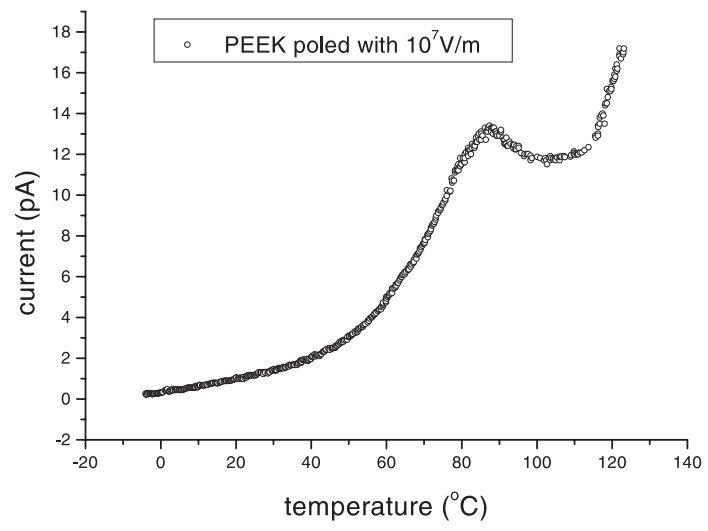

Figure 3. Thermally stimulated discharge current (TSDC) for PEEK poled at $150^{\circ} \mathrm{C}$ for $30 \mathrm{~min}$.
According to Van Turnhout [9] the peak observed in TSDC spectrum is related with the peak observed in dielectric loss by,

$\omega \frac{E_{a}}{h k T^{2}}$

where $\mathrm{w}$ is the angular frequency, $\mathrm{E}_{\mathrm{a}}$ is the activation energy of the process, $h$ is the reciprocal of heating rate, $\mathrm{k}=1.38 \times 10^{-23} \mathrm{~J} / \mathrm{K}$ is the Boltzmann constant and $\mathrm{T}$ is the temperature of maximum current in TSDC measurement.

The activation energy was calculated using the initial rise method [9]. The Arrhenius equation is:

$I=I_{0} \exp \left[\frac{-E_{a}}{k T}\right]$

and from the slope of the $\ln [\mathrm{I}] \times 1 / \mathrm{T}$ plot in figure 4 , the value of $\mathrm{E}_{\mathrm{a}}=0.44 \mathrm{eV}$ was found for the dipolar transition. That value of activation energy is in the range of the insulating polymers such as: polyethylene terephthalate $(0.62 \mathrm{eV})$ [10], polypropylene $(0.75 \mathrm{eV})$ [11] and low-density polyethylene $(0.60 \mathrm{eV})$ [12].

Using equation 4 and $\mathrm{E}_{\mathrm{a}}=0.44 \mathrm{eV}, \mathrm{k}=$ $1.38 \times 10^{-23} \mathrm{~J} / \mathrm{K}, \mathrm{h}=60 \mathrm{sec} /$ degree and $\mathrm{T}=365 \mathrm{~K}$, the corresponding peak in dielectric loss occurs at $1.0 \times 10^{-4} \mathrm{~Hz}$ as observed in figure 2 .

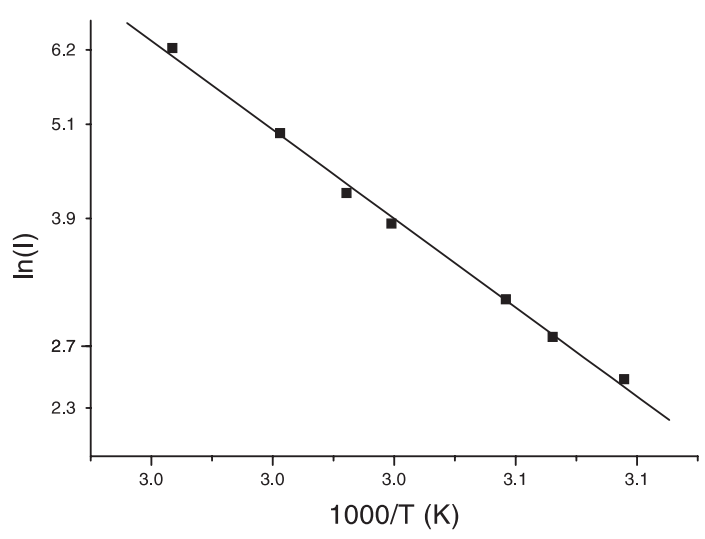

Figure 4. Plot of $\ln (\mathrm{I}) \mathrm{x} 1000 / \mathrm{T}$, using the initial rise method from TSDC measurement. 
Figure 5 shows typical discharging transients for different temperatures. For all temperatures the discharge current obey the empirical law:

$\mathrm{I}(\mathrm{t})=\mathrm{A}(\mathrm{t}) \mathrm{t}^{-\mathrm{n}}$

where $I(t)$ is the current at time $t$ after the removal of the electric field, $\mathrm{A}(\mathrm{t})$ is a temperature dependent material constant and $\mathrm{n}$ is an index roughly equal to 1 . The change in the slope at low frequency (long time) is an indicative of a low-frequency dispersion (LFD) [13] that can be better observed in the dielectric loss data. The increase of the dielectric loss values at low frequency is usually indicative of an ionic or electronic space charge mechanism [12] which is responsible for mask the peak in dielectric loss spectrum.

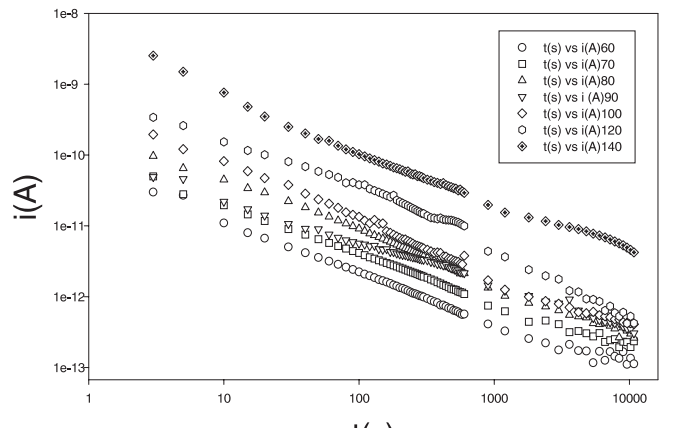

$\mathrm{t}(\mathrm{s})$
Some experiments are in progress in our lab to provide an analysis of the temperature and field dependence of the conduction currents in PEEK films. Also the TSDC spectra in lowtemperature range should be done for better understanding of the conduction mechanism.

\section{Conclusions}

An analysis of the dielectric loss and the thermally stimulated current spectra in PEEK films show a relaxation process in low-frequency range related with the glass transition temperature. It would appear from low-frequency dielectric loss and discharging transient that space charges are important to understand the conduction mechanism in the polymer and deserve more attention for a comprehensive explanation of the process.

\section{Acknowledgement}

I would like to express my deep grateful to Professor Ernesto Rafael Gonzalez for his teaching, not only on scientific side but also for his example of dignity and friendship during my $\mathrm{Ph} . \mathrm{D}$. To him I dedicate the present paper. Thanks also are due to Mr. Marcos Anicete dos Santos for his help on TSDC measurement.

Figure 5. Discharging currents in PEEK. Sample charged with $10^{5} \mathrm{~V} / \mathrm{m}$ for $27 \mathrm{~h}$

W. K. SAKAMOTO. Espectroscopia dielétrica e corrente de despolarização termo-estimulada em filmes de peek

Resumo: A permissividade complexa de filmes de poli(eter-eter-cetona) (PEEK) foram investigados num grande intervalo de frequência. Não foram observados picos de relaxação no intervalo de frequência de $1,0 \mathrm{~Hz}$ a $10^{5} \mathrm{~Hz}$, mas no intervalo de baixa frequência $\left(10^{-4} \mathrm{~Hz}\right)$ há uma evidência de pico, o qual também pode ser observado com medidas de corrente de despolarização termo-estimulada (TSDC). Este pico está relacionado com a transição vítrea do polímero. A energia de ativação relacionada a esta relaxação dipolar foi obtida e ovalor é $\mathrm{E}_{\mathrm{a}}=0,44 \mathrm{eV}$, que é similar à energia de ativação de muitos polímeros sintéticos. As cargas espaciais se mostraram importantes no mecanismo de condução como evidenciado nas medidas da corrente de despolarização.

Palavras-chave: perda dielétrica; corrente de despolarização termo-estimulada; energia de ativação; temperatura de transição vítrea. 


\section{References}

[1] Provisional data sheet PK PD1, "Grades, properties and processing characteristics", Imperial Chemical Industries (I.C.I.), UK. (1980).

[2] J. M. Charrier. "Polymeric Materials and Processing", Hanser Publishers, Munich p 144 - 145 (1991).

[3] P. J. Kimber, C. P. Smith, T. C. Stening, Modern Plastic (1981) 86.

[4] D. J. Kemish, J. N. Hay. Polymer 26 (1985) 905.

[5] Provisional data sheet PK PD16, "Electrical properties of Victrex PEEK", Imperial Chemical Industries Ltd. UK. (1980). $\{6\}$ B. V. Hamon. Proc. IEE, Part IV: Monograph, 99 (1952), 151.
[7] A. K. Jonscher. Universal Relaxation Law, Chelsea Dielectric Press, London (1996)

[8] W. K. Sakamoto, D. H. F. Kanda, D. K. Das-Gupta,. Mat. Research Innovation, 5, (2002) 257.

[9] J. Van Turnhout. "Thermally Stimulated Discharge of Electrets", In: Sessler, G. M. (ed.) Topics in Appied Phys. Electrets. Springer Berlin Heidelberg, New York (1980).

[10] D. K. Das-Gupta, K. Joyner. J. Phys. D. 9 (1976) 829.

[11] D. K. Das-Gupta, K. Joyner. J. Phys. D. 9 (1976) 2041

[12] D. K. Das-Gupta, R. S. Brockley. J. Phys. D. 11(1978) 955.

[13] A. K. Jonscher. J. Phys. D: Appl. Phys. 32(1999) R57.

[14] V. Daniel Vera, Dielectric Relaxation, Academic Press, London (1967) 